\title{
Effect of amino acid or casein supply on whole-body, splanchnic, and mammary glucose kinetics in lactating dairy cows
}

\author{
C. E. Galindo, ${ }^{\star}$ D. R. Ouellet, † D. Pellerin, ${ }^{\star}$ S. Lemosquet, $\neq$ I. Ortigues-Marty, $\S$ and H. Lapierre ${ }^{1}$ \\ *Département de Sciences Animales, Université Laval, Québec, QC, Canada, G1V 0A6 \\ †Dairy and Swine Research and Development Centre, Agriculture and Agri-Food Canada, STN Lennoxville, Sherbrooke, QC, Canada, J1M 1Z3 \\ fINRA, UMR1080, Dairy Production, F-35590 Saint Gilles, France \\ §INRA, UR1213, Unité de Recherches sur les Herbivores, Theix, 63122 St Genès Champanelle, France
}

\section{ABSTRACT}

This study was conducted to establish how AA supplied in a free form or as protein (casein, CN) affect the whole-body rate of appearance (WB Ra) of glucose, splanchnic and mammary glucose kinetics, and milk lactose secretion in lactating dairy cows. Five Holstein cows fitted with a rumen cannula and permanent indwelling catheters in the abomasum, portal, hepatic, and mesenteric veins, and one mesenteric artery, were used in a Youden square with 4 periods of $14 \mathrm{~d}$ each. Cows were fed a hay-based diet providing 100 and $70 \%$ of their net energy and metabolizable protein (MP) requirements, respectively. Treatments consisted of abomasal infusions of water $(70 \%$ of MP requirements: control, Con), free AA (95\% of MP requirements: AA1; and $120 \%$ of MP requirements: AA2), or CN (95\% of MP requirements: $\mathrm{CN} 1$ ). The free AA mixture had the same profile as $\mathrm{CN}$. On d 14 of each period, $\left[6,6-{ }^{2} \mathrm{H}_{2}\right]$ glucose $(25.8 \mathrm{mmol} / \mathrm{h})$ was infused into a jugular vein, and blood samples $(\mathrm{n}=8)$ were taken over $4 \mathrm{~h}$ from arterial, portal, hepatic, and mammary sources to measure glucose enrichment and concentration. Splanchnic and mammary plasma flows were determined by downstream dilution of para-aminohippurate and with the Fick principle, respectively. The last 6 milkings of each period were weighed and sampled to measure the yields of milk and components. The AA1 and CN1 treatments were not different for any of the measured parameters. Supplying AA linearly increased glucose WB Ra (AA2 vs. Con: $+151 \mathrm{mmol} / \mathrm{h}$ ) and liver net flux $(+149 \mathrm{mmol} / \mathrm{h})$. Utilization of glucose from the plasma compartment by the portal-drained viscera and liver and true portal absorption were not affected by AA supply. From these observations, we suggest that the increased WB Ra was due to increased net hepatic production. The AA from the infusion, in excess of that used to cover the increase in milk protein, were converted to glucose with an apparent efficiency close

Received November 1, 2010.

Accepted April 16, 2011.

${ }^{1}$ Corresponding author: Helene.Lapierre@agr.gc.ca to $100 \%$ of maximum theoretical efficiency. Milk and lactose yields increased linearly with infusions of AA, by 14 and $16 \%$ with AA2 treatment, respectively. However, mammary glucose uptake was not significantly altered by AA infusions; this suggests that the mammary gland exerts active control on the uptake and utilization of glucose. For all treatments, the sum of true portal glucose absorption and true hepatic glucose production contributed more than $99 \%$ of WB Ra in the lactating cow; this would suggest that renal glucose synthesis makes only a small contribution to WB Ra under these conditions.

Key words: dairy cow, glucose, amino acid, casein

\section{INTRODUCTION}

Early studies conducted in sheep reported that very little glucose was net absorbed into the portal circulation (Bensadoun et al., 1962). These observations were later supported in cattle where net portal appearance of glucose was not significantly different from zero, averaging $4 \pm 13 \mathrm{~g} / \mathrm{d}$ across 306 measurements (Reynolds, 2006). Furthermore, if all the glucose entering the duodenum were absorbed, it would equal less than $10 \%$ of whole-body (WB) glucose utilization in growing animals (Otchere et al., 1974; Young, 1977). In lactating dairy cows, glucose requirements are further increased by mammary gland (MG) demand, including milk lactose secretion, with glucose being the main precursor (Bickerstaffe et al., 1974). This demand creates a greater deficit in lactating ruminants in terms of dietary glucose provision, which must be met by gluconeogenesis. In sheep, glucose synthesis contributed $85 \%$ of the WB rate of appearance (WB Ra) of glucose (Bergman et al., 1970). Major glucose precursors include propionate, lactate, AA, and glycerol (Young, 1977). Gluconeogenesis occurs mainly in the liver, but the kidneys also contribute 8 to $16 \%$ of the WB Ra of glucose in sheep (Bergman et al., 1974).

In fed ruminants, propionate is considered the major precursor of glucose (Reynolds, 2006), whereas estimates of the maximum contribution of AA to glucose synthesis vary between 5 and 30\% (Lindsay, 1980; 
Reynolds et al., 1992; Lozano et al., 2000). In dairy cows, postruminal infusions of $\mathrm{CN}$ increased, at least numerically, the WB Ra of glucose as well as milk yield (Clark et al., 1977; König et al., 1984; Lemosquet et al., 2009). Estimates of the WB Ra of glucose represent the sum of glucose synthesis, glucose absorption, and glycogenolysis; in this context, glucose synthesis represents total glucose production and therefore includes synthesis from recycled glucose carbons. Therefore, the increment in WB Ra observed with CN supply may result from increased glucose synthesis from AA, from decreased utilization of dietary glucose by the enterocytes, from increased turnover of the glycogen pool, or from a combination of those events. In growing sheep, CN infusion did not affect net portal absorption or utilization of arterial glucose by the portal-drained viscera (PDV; El-Kadi et al., 2006), but the situation might be different in high-yielding dairy cows. No studies have yet compared the variation in WB Ra of glucose and liver release of glucose in response to AA supplementation.

Choung and Chamberlain (1995) reported that infusions of $\mathrm{CN}$ or free AA into the abomasum of dairy cows caused similar increases in milk protein and lactose yields at the highest dose tested, but milk fat concentration was greater with the free AA infusion. Therefore, the form in which AA are infused (i.e., protein vs. free AA) may have an effect on energy metabolism, including glucose response to AA supply.

The hypotheses of the present study were that an increased AA supply (1) is associated with increased WB Ra of glucose through an increased net hepatic release, with implications for mammary glucose uptake and milk lactose yield; (2) decreases utilization of glucose by the PDV that would also spare glucose for MG use; and that either or both processes are altered by the form of AA supplied. Therefore, the objectives of this experiment were to determine how a supply of AA affects the following: (1) the WB Ra of glucose; (2) the contribution of the true fluxes of glucose across the PDV and liver to WB Ra; (3) the contribution of the utilization of glucose by the PDV, liver, and MG to WB glucose utilization; and (4) the relationship between the WB Ra of glucose, mammary glucose uptake, and milk lactose yield. A further objective was to determine whether AA have a similar effect on these parameters if the AA are supplied in a free form or as protein $(\mathrm{CN})$.

\section{MATERIALS AND METHODS}

\section{Animals and Treatments}

Five lactating Holstein cows in their second lactation, averaging (mean $\pm \mathrm{SD}$ ) $626 \pm 61 \mathrm{~kg}$ of $\mathrm{BW}$ and
$77 \pm 13$ DIM at the beginning of the experiment, were used for the present study. The cows had been fitted before calving with a rumen cannula (4.5 inches in diameter; Bar Diamond Inc., Parma, ID) according to the method of Duffield (1999). Approximately $8 \mathrm{wk}$ after calving, the cows were surgically implanted with catheters, 1 in the abomasum (Doepel et al., 2006) and 2 in mesenteric veins, 1 in a mesenteric artery, 1 in the portal vein, and 1 in a hepatic vein (Huntington et al., 1989). During the surgery, the right carotid artery was raised to a subcutaneous position to provide access to arterial blood if necessary.

Throughout the experiment, the cows were fed the same basal diet, which was balanced to provide $100 \%$ of their energy requirements but only $70 \%$ of their MP requirements, for an estimated milk production of $32.8 \mathrm{~kg} / \mathrm{d}(3.74 \%$ fat and $3.32 \% \mathrm{CP})$ and fed at $97 \%$ of ad libitum intake (measured the week before the start of the project; NRC, 2001; Table 1). The basal diet, as hay and concentrate (Table 2), was offered in equal meals every $2 \mathrm{~h}$ from automated feeders (Ankom Technology, Fairport, NY). The hay was chopped to facilitate delivery through the automated feeders, with the exception of $1 \mathrm{~kg}$ of long hay that was offered once a day to prevent ruminal disturbances. The cows had free access to water and were housed in a tie-stall barn. Feed offered and orts were weighed daily. Samples of feed ingredients were collected weekly and frozen. The cows were milked twice daily (at 0800 and $2000 \mathrm{~h}$ ) and yield was recorded at each milking. On the last $3 \mathrm{~d}$ of each 14-d experimental period, milk was sampled at each milking, and the samples were frozen for further analysis. The experimental protocol was approved by the Institutional Committee for Animal Care at Agriculture and Agri-Food Canada's Dairy and Swine Research and Development Centre in Sherbrooke (QC, Canada), and the animals were cared for in accordance with the guidelines of the Canadian Council on Animal Care (1993).

The infusion of AA or $\mathrm{CN}$ was evaluated according to a $4 \times 4$ Youden square, with 5 cows, 4 treatments, and 4 periods of $14 \mathrm{~d}$ each. The 4 treatments consisted of continuous infusions $(12 \mathrm{~kg} / \mathrm{d})$ into the abomasum of a solution by means of a peristaltic pump. The treatments were as follows: (1) water (control, Con); (2) a mixture of AA (Table 3) estimated to meet, with the basal diet, 95\% of MP requirements (AA1: $691.2 \mathrm{~g} / \mathrm{d}$ ); (3) the same mixture of AA, but at twice the infusion rate, estimated to cover 120\% of MP requirements (AA2: 1,382.3 $\mathrm{g} / \mathrm{d}$ ); and (4) CN estimated to supply the same amount and profile of AA as AA1 (CN1: $647.4 \mathrm{~g} / \mathrm{d}$ of sodium caseinate; NZMP Sodium Caseinate 180, Nealanders International Inc., Mississauga, ON, Canada). The profile of the mixture of AA was based on $\mathrm{CN}$ composition, 
Table 1. Composition of the experimental diet

\begin{tabular}{lc}
\hline Item & $\begin{array}{c}\mathrm{g} / \mathrm{kg} \\
\text { of DM }\end{array}$ \\
\hline Ingredient & \\
Grass hay, mature & 429 \\
Wheat middlings & 63 \\
Corn grain, ground & 124 \\
Barley, ground & 257 \\
Beet sugar pulp, dried & 72 \\
Megalac Low Odor ${ }^{1}$ & 28 \\
Urea & 5 \\
Mineral and vitamin premix & 22 \\
Estimate from NRC (2001) ${ }^{2}$ & \\
NE $($ Mcal/d) & 33.8 \\
CP (\% of DM) & 12 \\
RDP (g/d) & 1,796 \\
RUP (g/d) & 741 \\
MP (g/d) & 1,618 \\
From microbial protein & 977 \\
From undegraded feed & 541 \\
From endogenous origin & 100 \\
\hline
\end{tabular}

${ }^{1}$ Church \& Dwight Co. Inc. (Princeton, NJ).

${ }^{2}$ Calculated using the intake observed during the study for the control treatment, with chemical composition of the feed ingredients reported in Table 2 .

except that Tyr was replaced by Phe and part of the Glu by Gln, due to solubility constraints (Table 4). The AA composition was obtained after protein hydrolysis, as described by Borucki Castro et al. (2008); for AA requiring special hydrolysis conditions (i.e., Cys, Met, and Trp), and for Asx and Glx, the manufacturer's composition was used. To partition Asx into Asn and Asp and Glx into Gln and Glu, their relative proportions in milk protein (Swaisgood, 1995) were used. The AA solutions were diluted daily from a stock solution prepared every 2 or $3 \mathrm{~d}$, whereas the $\mathrm{CN}$ solutions were prepared fresh daily. Two cows received treatments through an abomasal tube installed via the rumen cannula (Gressley et al., 2006) because the abomasal catheters did not function well.

\section{Blood Sampling}

On d 14, at the end of each period, para-aminohippurate $(\boldsymbol{p A H} ; 14.4 \mathrm{~g} / \mathrm{h})$ was infused continuously from
0815 to $1315 \mathrm{~h}$ into 1 mesenteric vein with a syringe pump to determine portal and splanchnic plasma flows by downstream dilution of $p \mathrm{AH}$ (Katz and Bergman, 1969). In addition, starting at $1045 \mathrm{~h},\left[6,6-{ }^{2} \mathrm{H}_{2}\right]$ glucose $(25.8 \pm 0.2 \mathrm{mmol} / \mathrm{h}, 99$ mole percent excess (MPE); Cambridge Isotope Laboratories Inc., Andover, MA), preceded by a priming dose of $13 \mathrm{mmol}$, was infused into a jugular vein until the end of the blood sampling to determine the WB Ra of glucose and glucose utilization across tissues. Starting after at least $45 \mathrm{~min}$ of $p \mathrm{AH}$ infusion, 8 blood samples were taken as follows: 3 samples at 40-min intervals, before the infusion of labeled glucose $(0900,0940$, and $1020 \mathrm{~h})$ and 5 samples at 20-min intervals, starting $1 \mathrm{~h}$ after the initiation of the labeled glucose infusion $(1145,1205,1225,1245$ $\mathrm{h}$, and $1305 \mathrm{~h}$ ). Blood was taken simultaneously from the arterial, portal, and hepatic vein catheters on all sampling times and from the mammary vein by venipuncture only for the samples taken at 40-min intervals ( $\mathrm{n}=6$ : 0900, 0940, 1020, 1145, 1225, and $1305 \mathrm{~h})$. Immediately after sampling, the blood was transferred from the syringes to heparinized tubes and kept on ice before centrifugation at $1,800 \times g$ for $12 \mathrm{~min}$. The plasma was subsampled for $p \mathrm{AH}$ analysis on the day of sampling using a Technicon AutoAnalyzer system (Seal Analytical Inc., Mequon, WI; Eisemann et al., 1987) An additional $1 \mathrm{~g}$ of plasma was gravimetrically weighed and mixed with $0.2 \mathrm{~g}$ of $\left[\mathrm{U}_{-}{ }^{13} \mathrm{C}\right]$ glucose solution (98\% MPE; Cambridge Isotope Laboratories Inc.) to allow determination of glucose concentration. The morning of each sampling day, before the start of the $p \mathrm{AH}$ infusion, a sample was collected from each sampling site to determine natural abundance. The plasma was stored at $-80^{\circ} \mathrm{C}$ for further analysis. All analyses were performed on individual samples.

\section{Laboratory Analysis}

Samples of feed ingredients, composited by period, were freeze-dried, ground in a Wiley mill with a 1-mm screen (standard model 4; Arthur H. Thomas Co., Phil-

Table 2. Chemical composition of the feed ingredients of the experimental diet

\begin{tabular}{lccccc}
\hline & \multicolumn{5}{c}{ Feed ingredients } \\
\cline { 2 - 6 } $\begin{array}{l}\text { Analyses } \\
\text { (\% DM) }\end{array}$ & $\begin{array}{c}\text { Grass hay, } \\
\text { mature }\end{array}$ & $\begin{array}{c}\text { Wheat } \\
\text { middlings }\end{array}$ & $\begin{array}{c}\text { Corn grain, } \\
\text { ground }\end{array}$ & $\begin{array}{c}\text { Barley, } \\
\text { ground }\end{array}$ & $\begin{array}{c}\text { Beet sugar } \\
\text { pulp, dried }\end{array}$ \\
\hline CP & 8.99 & 20.71 & 9.10 & 12.07 & 9.60 \\
ADF & 30.21 & 12.94 & 2.04 & 5.64 & 24.41 \\
NDF & 57.97 & 40.94 & 9.31 & 18.82 & 39.19 \\
Lignin & 4.06 & 2.87 & 0.65 & 1.32 & 2.74 \\
Acid detergent insoluble protein & 1.10 & 1.40 & 0.30 & 0.50 & 0.60 \\
Neutral detergent insoluble protein & 7.40 & 2.80 & 0.70 & 1.80 & 5.50 \\
Ash & 7.00 & 6.30 & 1.50 & 2.90 & 7.30 \\
Lipid & 2.00 & 4.30 & 4.20 & 2.20 & 1.10 \\
\hline
\end{tabular}


Table 3. Rate of infusion of AA from the mixture of AA or from sodium caseinate

\begin{tabular}{lrrr}
\hline & \multicolumn{3}{c}{ Treatment $^{1}$} \\
\cline { 2 - 4 } AA $(\mathrm{g} / \mathrm{d})$ & $\mathrm{AA} 1$ & $\mathrm{AA} 2$ & $\mathrm{CN} 1$ \\
\hline Essential AA & & \\
Arginine & 25.0 & 49.9 & 25.0 \\
Histidine & 18.6 & 37.3 & 18.6 \\
Isoleucine & 33.7 & 67.3 & 33.7 \\
Leucine & 63.0 & 126.0 & 63.0 \\
Lysine & 52.9 & 105.9 & 52.9 \\
Methionine & 19.6 & 39.1 & 19.6 \\
Phenylalanine & 72.0 & 143.9 & 34.8 \\
Threonine & 29.3 & 58.6 & 29.3 \\
Tryptophan & 8.1 & 16.2 & 8.1 \\
Valine & 38.3 & 76.6 & 38.3 \\
Total essential AA & 360.4 & 720.9 & 323.2 \\
Nonessential AA & & & \\
Alanine & 20.8 & 41.6 & 20.8 \\
Aspartate & 20.8 & 41.7 & 20.8 \\
Asparagine & 25.7 & 51.5 & 25.7 \\
Cysteine & 2.7 & 5.4 & 2.7 \\
Glutamate & 51.6 & 103.2 & 79.4 \\
Glutamine & 89.5 & 179.0 & 61.7 \\
Glycine & 12.6 & 25.1 & 12.6 \\
Proline & 71.7 & 143.5 & 71.7 \\
Serine & 38.6 & 77.1 & 38.6 \\
Tyrosine & - & - & 37.2 \\
Total nonessential AA & 334.0 & 668.1 & 371.2 \\
\hline Abomasa inf & & \\
\hline
\end{tabular}

${ }^{1}$ Abomasal infusion treatments: AA1 $=$ free AA for a total supply at $95 \%$ of MP requirements; AA2 = free AA for a total supply at $120 \%$ of MP requirements; $\mathrm{CN} 1$ = sodium caseinate for a total supply at $95 \%$ of MP requirements.

adelphia, PA), and analyzed for CP, ADF, NDF, lignin, ADIN, NDIN, ash, and lipid as described previously (Martineau et al., 2007; Table 2). Each milk sample was analyzed for concentrations of total $\mathrm{N}$ determined by combustion (protein as $\mathrm{N} \times 6.38$; Nitrogen Determinator, model FP-428; Leco Corp., St. Joseph, MI) and lactose using a diagnostic kit (Megazyme International Ireland Ltd., Bray, Co. Wicklow, Ireland; distributed by Xygen Diagnostics Inc., Burgessville, ON, Canada). Samples were pooled by cow $\times$ period for NPN and noncasein N, which were analyzed as described previously (Raggio et al., 2004).

Glucose enrichment and concentration were analyzed on the same sample, through monitoring of, respectively, ions 242 and 244 (for the infused $\left[6,6-{ }^{2} \mathrm{H}_{2}\right]$ glucose) and ions 242 and 247 (for the $\left[\mathrm{U}_{-}{ }^{13} \mathrm{C}\right]$ glucose added to the samples as the internal standard). Briefly, the samples were deproteinized with a 2:1 mixture of acetonitrile and ethanol. The derivatization was performed with acetic anhydride and pyridine by the addition of acetonitrile to form the aldonitrile pentaacetate derivative of glucose. The mass of ions was quantified by GC-MS (GC 8090 coupled to MS 5973; Agilent Technologies, Wilmington, DE) in electron impact mode. Glucose concentration was determined by isotope dilution
Table 4. Profile of the infused sodium caseinate ${ }^{1}$

\begin{tabular}{lc}
\hline AA & Composition $^{2}$ \\
\hline Arginine & 38.6 \\
Histidine & 28.8 \\
Isoleucine & 52.0 \\
Leucine & 97.3 \\
Lysine & 81.8 \\
Methionine & 30.2 \\
Phenylalanine & 53.7 \\
Threonine & 45.3 \\
Tryptophan & 12.5 \\
Valine & 59.2 \\
Alanine & 32.1 \\
Aspartate & 32.2 \\
Asparagine & 39.8 \\
Cysteine & 4.2 \\
Glutamate & 122.7 \\
Glutamine & 95.3 \\
Glycine & 19.4 \\
Proline & 110.8 \\
Serine & 59.6 \\
Tyrosine & 57.5 \\
\hline
\end{tabular}

${ }^{1}$ NZMP Sodium Caseinate 180 , Nealanders International Inc. (Mississauga, ON, Canada).

${ }^{2}$ Grams of AA per kilogram of sodium caseinate, as is.

(Calder et al., 1999), taking into account the presence of the labeled glucose from the infusion.

\section{Calculations and Statistical Analyses}

Because the plasma isotopic enrichment (IE) of glucose did not reach a plateau (see results below), WB $\mathrm{Ra}$ of glucose was calculated using a non-steady-state model, as proposed by Brockman (1984). Briefly, WB Ra of glucose for each cow $\times$ period was estimated as the average of the following calculation, estimated for each sampling interval:

$$
\mathrm{WB} R \mathrm{Ra}=\frac{\mathrm{F}-\mathrm{p} \times \mathrm{V} \times[\mathrm{A}] \times \Delta \mathrm{IE}_{\mathrm{A}} / \Delta \mathrm{t}}{\mathrm{IE}_{\mathrm{A}}}-\mathrm{F},
$$

where WB Ra is expressed in $\mathrm{mmol} / \mathrm{h}$; $\mathrm{F}$ is the rate of infusion $(\mathrm{mmol} / \mathrm{h})$ of $\left[6,6-{ }^{2} \mathrm{H}_{2}\right]$ glucose; $[\mathrm{A}](\mathrm{m} M)$ and $\mathrm{IE}_{\mathrm{A}}(\mathrm{MPE})$ are the means of arterial plasma concentration and IE, respectively, over the time interval; $\Delta \mathrm{IE}_{\mathrm{A}}$ (MPE) is the variation of arterial plasma $\left[6,6-{ }^{2} \mathrm{H}_{2}\right]$ glucose IE, and $\Delta \mathrm{t}$ the time interval for which Ra was calculated; V represents the distribution volume of glucose and was estimated as $110 \mathrm{~mL} / \mathrm{kg} \mathrm{BW}$ (Lemosquet et al., 2004), and a pool fraction $\mathrm{p}=0.65$ was used, as proposed by Brockman (1984).

Net portal (PDV), splanchnic (TSP), hepatic (HEP), and mammary (MG) fluxes of glucose were calculated with the following equations (see next paragraph for an explanation of the variables): 


$$
\begin{aligned}
\text { PDV flux }= & ([\mathrm{P}]-[\mathrm{A}]) \times \mathrm{ppf}-\left([\mathrm{P}] \times \mathrm{IE}_{\mathrm{P}}\right. \\
- & {\left.[\mathrm{A}] \times \mathrm{IE}_{\mathrm{A}}\right) \times \mathrm{ppf}, } \\
\text { TSP flux }=([\mathrm{H}]-[\mathrm{A}]) \times \text { tsppf }-\left([\mathrm{H}] \times \mathrm{IE}_{\mathrm{H}}-[\mathrm{A}]\right. & \left.\times \mathrm{IE}_{\mathrm{A}}\right) \times \text { tsppf, } \\
\text { HEP flux }= & (\mathrm{TSP} \text { flux })-(\mathrm{PDV} \text { flux }), \text { and } \\
\text { MG flux }= & ([\mathrm{M}]-[\mathrm{A}]) \times \operatorname{mpf}-\left([\mathrm{M}] \times \mathrm{IE}_{\mathrm{M}}\right. \\
& \left.-[\mathrm{A}] \times \mathrm{IE}_{\mathrm{A}}\right) \times \operatorname{mpf} .
\end{aligned}
$$

The PDV, TSP, HEP, and MG utilization of glucose from plasma supply (plasma utilization, $\mathbf{P U}$; $\mathbf{P D V}_{\mathbf{P U}}$, $\mathbf{T S P}_{\mathbf{P U}}, \mathbf{H E P}_{\mathbf{P U}}$, and $\mathbf{M G}_{\mathbf{P U}}$, respectively) were calculated with the following equations:

$$
\begin{aligned}
& \mathrm{PDV}_{\mathrm{PU}}=\left[\left([\mathrm{P}] \times \mathrm{IE}_{\mathrm{P}}-[\mathrm{A}] \times \mathrm{IE}_{\mathrm{A}}\right) / \mathrm{IE}_{\mathrm{A}}\right] \times \mathrm{ppf} \\
&-\left([\mathrm{P}] \times \mathrm{IE}_{\mathrm{P}}-[\mathrm{A}] \times \mathrm{IE}_{\mathrm{A}}\right) \times \mathrm{ppf}, \\
& \mathrm{TSP}_{\mathrm{PU}}=\left[\left([\mathrm{H}] \times \mathrm{IE}_{\mathrm{H}}-[\mathrm{A}] \times \mathrm{IE}_{\mathrm{A}}\right) / \mathrm{IE}_{\mathrm{A}}\right] \times \mathrm{tsppf} \\
&-\left([\mathrm{H}] \times \mathrm{IE}_{\mathrm{H}}-[\mathrm{A}] \times \mathrm{IE}_{\mathrm{A}}\right) \times \mathrm{tsppf}, \\
& \mathrm{HEP}_{\mathrm{PU}}=\left(\mathrm{TSP}_{\mathrm{PU}}-\mathrm{PDV}_{\mathrm{PU}}\right), \text { and } \\
& \mathrm{MG}_{\mathrm{PU}}=\left[\left([\mathrm{M}] \times \mathrm{IE}_{\mathrm{M}}-[\mathrm{A}] \times \mathrm{IE}_{\mathrm{A}}\right) / \mathrm{IE}_{\mathrm{A}}\right] \times \mathrm{mpf} \\
&-\left([\mathrm{M}] \times \mathrm{IE}_{\mathrm{M}}-[\mathrm{A}] \times \mathrm{IE}_{\mathrm{A}}\right) \times \mathrm{mpf},
\end{aligned}
$$

where $[\mathrm{A}],[\mathrm{P}],[\mathrm{H}]$, and $[\mathrm{M}]$ are the arterial, portal, hepatic, and mammary concentrations $(\mathrm{m} M)$, respectively; $\mathrm{IE}_{\mathrm{A}}, \mathrm{IE}_{\mathrm{P}}, \mathrm{IE}_{\mathrm{H}}$, and $\mathrm{IE}_{\mathrm{M}}$ are the enrichment (MPE) of $\left[6,6-{ }^{2} \mathrm{H}_{2}\right]$ glucose in the artery and the portal, hepatic, and mammary veins, respectively; and ppf, tsppf, and mpf are the portal, splanchnic, and mammary plasma flows $(\mathrm{L} / \mathrm{h})$, respectively. The last portion of each equation removes the movement of the tracer, leaving just tracee movement, and was applied to the net fluxes only for samples that were collected during the infusion of the tracer. The removal of tracer movement from $\mathrm{PU}$ is based on a concept similar to the removal of the rate of infusion from the equation for WB Ra. A single estimation of the precursor pool for PU was used, the arterial IE, to simplify the comparison between tissues and WB.

Because utilization and absorption or production can occur simultaneously in a tissue, the utilization from plasma supply needs to be added to the net flux to yield the "true" flux, as proposed by Bergman et al.
(1970). This represents either true absorption across the PDV, true production across the liver, or true release across the TSP. The true PDV, TSP, and HEP fluxes of glucose were, therefore, calculated with the following equations:

$$
\begin{gathered}
\text { True PDV }=\text { PDV flux }+\mathrm{PDV}_{\mathrm{PU}}, \\
\text { True TSP }=\text { TSP flux }+\mathrm{TSP}_{\mathrm{PU}}, \\
\text { True HEP }=\text { true TSP }- \text { true PDV. }
\end{gathered}
$$

The data were averaged per cow $\times$ period and analyzed according to the following model for a Youden square, using the Mixed procedure of SAS (SAS Institute, 2008), with treatment, period, and cow as fixed effects:

$$
Y_{i j k}=\mu+C_{i}+P_{j}+T_{k}+\varepsilon_{i j k},
$$

where $Y$ is the observed value for the $k^{n}$ treatment, the $j^{n}$ period, and $i^{n}$ cow; $\mu$ is the grand mean; $C_{i}, P_{j}$, and $T_{k}$ are the cow, period, and treatment effects, respectively; and $\varepsilon_{i j k}$ is the random error associated with $Y_{i j k}$. In addition, the effect of time of sampling was tested as a repeated measurement with the Mixed procedure of SAS. The results are expressed as LSM with SEM. Two orthogonal contrasts (linear and quadratic) were used to test the effect of the infusion of free AA using the Con, AA1, and AA2 treatments, and a qualitative contrast was used to compare AA1 and $\mathrm{CN} 1$; that is, the same pattern and dose of AA infused in a free form or as a protein. A linear effect indicates that the difference between the first and last levels is significant, and the quadratic component indicates the lack of fit of the intermediary level for a linear relationship (Gill, 1978). Significance was declared at $P \leq 0.05$, with a tendency at $0.05<P \leq 0.10$.

\section{RESULTS}

\section{Intake, Milk Production, and Milk Composition}

Dry matter intake was not affected by infusions of AA, free or as protein (Table 5). Milk production increased linearly $(P=0.01)$ with the AA infusions. Yields of $\mathrm{CP}$ and lactose also increased linearly with AA infusions $(P<0.01)$, whereas milk production and milk CP and lactose yields did not differ between CN1 and AA1 (Table 5). The AA infusions linearly increased $(P<0.01)$ milk $\mathrm{CP}$ and true protein concentrations, but decreased $(P<0.01)$ the ratio of true protein to $\mathrm{CP}$, whereas the proportion of the $\mathrm{CN}$ fraction relative to $\mathrm{CP}$ did not change. Overall, $\mathrm{CP}$ and true protein 
Table 5. Effects of abomasal infusion of AA or CN on DMI, milk yield, and milk composition ${ }^{1}$

\begin{tabular}{|c|c|c|c|c|c|c|c|c|}
\hline Item & \multicolumn{4}{|c|}{ Treatment $^{2}$} & SEM & \multicolumn{3}{|c|}{$P$-value ${ }^{3}$} \\
\hline Milk (kg/d) & 30.9 & 32.7 & 35.3 & 32.9 & 1.0 & 0.01 & 0.72 & 0.88 \\
\hline $\mathrm{CP}(\mathrm{g} / \mathrm{d})$ & 951 & 1,082 & 1,206 & 1,058 & 26 & $<0.01$ & 0.92 & 0.53 \\
\hline \multicolumn{9}{|l|}{ Milk composition ${ }^{4}$} \\
\hline $\mathrm{CP}(\%)$ & 3.07 & 3.32 & 3.40 & 3.23 & 0.04 & $<0.01$ & 0.17 & 0.17 \\
\hline True protein (\%) & 2.95 & 3.17 & 3.21 & 3.09 & 0.04 & $<0.01$ & 0.13 & 0.22 \\
\hline True protein $(\%$ of $\mathrm{CP})$ & 95.9 & 95.5 & 94.3 & 95.7 & 0.1 & $<0.01$ & 0.15 & 0.48 \\
\hline $\mathrm{CN}(\%$ of $\mathrm{CP})$ & 83.5 & 83.5 & 83.5 & 83.9 & 0.3 & 0.96 & 0.92 & 0.40 \\
\hline Lactose (\%) & 4.59 & 4.63 & 4.66 & 4.51 & 0.40 & 0.27 & 0.89 & 0.06 \\
\hline
\end{tabular}

${ }^{1}$ Data are presented as LSM with SEM, given for $\mathrm{n}=5 ; 20$ observations.

${ }^{2}$ Abomasal infusion treatments: Con = water; AA1 = free AA for a total supply at $95 \%$ of MP requirements; AA2 = free AA for a total supply at $120 \%$ of MP requirements; CN1 = sodium caseinate for a total supply at $95 \%$ of MP requirements.

${ }^{3}$ Probability corresponding to the null hypothesis with 3 contrasts: AA linear $=$ contrast Con versus AA2; AA quadratic $=$ contrast Con and $\mathrm{AA} 2$ versus $\mathrm{AA} 1$; and $\mathrm{CN} 1$ versus $\mathrm{AA} 1$.

${ }^{4}$ Calculated from the average data of the last $3 \mathrm{~d}$ of each period.

yields increased linearly $(P<0.01)$ with AA infusion and did not differ between AA1 and CN1. Milk lactose concentration was not altered by the AA infusions but tended to decrease with CN1 compared with AA1 infusion $(P=0.06$; Table 5$)$.

\section{Plasma Flows and Net Flux of Glucose}

The portal, splanchnic, and mammary plasma flows were not affected by the AA infusions. However, the splanchnic plasma flow decreased by $114 \mathrm{~L} / \mathrm{h}$ during CN infusion compared with AA1 $(P=0.05$; Table 6$)$.

A linear increase $(P=0.02)$ was observed for hepatic glucose concentration and a tendency $(P=0.07)$ was observed for arterial glucose concentration to increase linearly in response to AA infusions, whereas the portal and mammary concentrations were not affected (Table $6)$. Net portal flux was not altered by the treatments. The AA infusions linearly increased $(P=0.02)$ the net hepatic and total splanchnic fluxes of glucose but did

Table 6. Effects of abomasal infusion of AA or CN on plasma flow, concentration, and net flux of glucose ${ }^{1}$

\begin{tabular}{|c|c|c|c|c|c|c|c|c|}
\hline \multirow[b]{2}{*}{ Item } & \multicolumn{4}{|c|}{ Treatment $^{2}$} & \multirow[b]{2}{*}{ SEM } & \multicolumn{3}{|c|}{$P$-value ${ }^{3}$} \\
\hline & Con & AA1 & AA2 & CN1 & & $\begin{array}{c}\text { AA } \\
\text { linear }\end{array}$ & $\begin{array}{c}\text { AA } \\
\text { quadratic }\end{array}$ & $\begin{array}{c}\text { CN1 vs. } \\
\text { AA1 }\end{array}$ \\
\hline \multicolumn{9}{|c|}{ Plasma flow (L/h) } \\
\hline Portal & 1,137 & 1,186 & 1,206 & 1,119 & 27 & 0.11 & 0.69 & 0.12 \\
\hline Splanchnic & 1,306 & 1,381 & 1,314 & 1,267 & 36 & 0.86 & 0.14 & 0.05 \\
\hline Mammary & 619 & 604 & 618 & 645 & 21 & 0.99 & 0.60 & 0.21 \\
\hline \multicolumn{9}{|c|}{ Glucose concentration $(\mathrm{m} M)$} \\
\hline Arterial & 3.61 & 3.77 & 3.77 & 3.78 & 0.05 & 0.07 & 0.26 & 0.95 \\
\hline Portal & 3.68 & 3.84 & 3.83 & 3.84 & 0.06 & 0.12 & 0.28 & 0.95 \\
\hline Hepatic & 4.02 & 4.22 & 4.28 & 4.27 & 0.06 & 0.02 & 0.46 & 0.57 \\
\hline Mammary & 2.82 & 2.89 & 2.90 & 2.89 & 0.06 & 0.39 & 0.79 & 0.91 \\
\hline \multicolumn{9}{|c|}{ Net flux $(\mathrm{mmol} / \mathrm{h})$} \\
\hline Portal & 78 & 74 & 76 & 65 & 16 & 0.95 & 0.90 & 0.68 \\
\hline Hepatic & 456 & 519 & 605 & 556 & 37 & 0.02 & 0.80 & 0.50 \\
\hline Splanchnic & 535 & 597 & 682 & 614 & 37 & 0.02 & 0.81 & 0.75 \\
\hline Mammary & 474 & 519 & 523 & 571 & 35 & 0.35 & 0.65 & 0.33 \\
\hline
\end{tabular}

${ }^{1}$ Data are presented as LSM with SEM, given for $\mathrm{n}=5$; 20 observations.

${ }^{2}$ Abomasal infusion treatments: Con $=$ water; AA1 = free AA for a total supply at $95 \%$ of MP requirements; AA2 = free AA for a total supply at $120 \%$ of MP requirements; CN1 = sodium caseinate for a total supply at $95 \%$ of MP requirements.

${ }^{3}$ Probability corresponding to the null hypothesis with 3 contrasts: AA linear $=$ contrast Con versus AA2; AA quadratic $=$ contrast Con and $\mathrm{AA} 2$ versus $\mathrm{AA} 1$; and $\mathrm{CN1}$ versus AA1. 
not alter mammary net flux. For all these parameters, treatments AA1 and CN1 did not differ.

\section{WB Ra of Glucose and Glucose Utilization by Tissues}

The arterial, portal, hepatic, and mammary IE of glucose decreased linearly $(P<0.01)$ with AA infusions but did not differ between AA1 and CN1 (Table 7). The IE of glucose in each vessel increased with time of sampling $(P<0.01$; Figure 1$)$, but no interaction was observed for treatment $\times$ time of sampling $(P>$ $0.35)$. The WB Ra of glucose, calculated with the nonsteady-state model, increased linearly $(P<0.01)$ with AA infusions and did not differ between AA1 and CN1 (Table 7).

Portal, hepatic, and splanchnic utilization of glucose from plasma supply were not affected by either time of sampling or treatments. Thus, the ratio $\mathrm{PDV}_{\mathrm{PU}} / \mathrm{WB}$ Ra tended $(P=0.07)$ to decrease with increased AA supply. Hepatic utilization of glucose by the liver did not differ from zero, and the proportion of $\mathrm{HEP}_{\mathrm{PU}} / \mathrm{WB}$ Ra was not affected by the treatments.

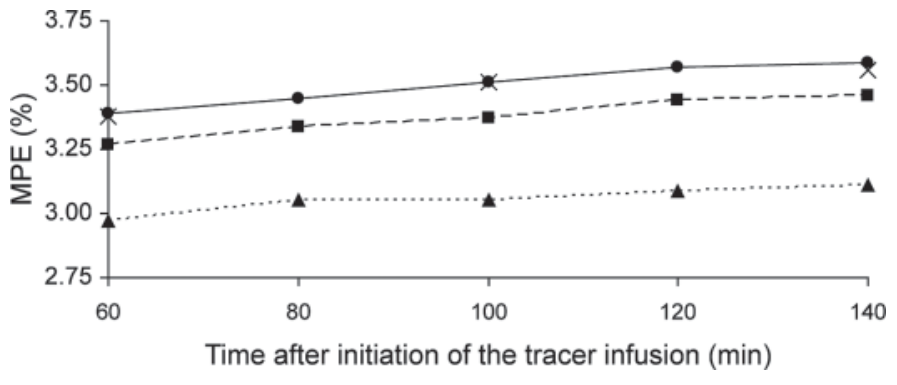

Figure 1. Isotopic enrichment (mole percent excess, MPE) of glucose in arterial $(\bullet)$, portal $(\mathbf{\square})$, hepatic $(\mathbf{\Lambda})$, and mammary $(\times)$ plasma during a primed continuous infusion of $\left[{ }^{2} \mathrm{H}_{2}\right]$ glucose in dairy cows; SEM averaged $0.040,0.043,0.035$, and $0.033 \%$ for arterial, portal, hepatic, and mammary isotopic enrichment, respectively.

The MG was the major user of glucose; total utilization did not differ between treatments and averaged 0.73 of WB Ra. Similarly, the ratio of milk lactose yield to WB Ra (lactose/WB Ra) and milk lactose yield to mammary net glucose flux (lactose/MG flux) were not affected by the treatments and averaged 0.53 and 0.73 , respectively (Table 7 ).

Table 7. Effects of abomasal infusion of amino acids or casein on glucose enrichment and total utilization ${ }^{1}$

\begin{tabular}{|c|c|c|c|c|c|c|c|c|}
\hline \multirow[b]{2}{*}{ Item } & \multicolumn{4}{|c|}{ Treatment $^{2}$} & \multirow[b]{2}{*}{ SEM } & \multicolumn{3}{|c|}{$P$-value ${ }^{3}$} \\
\hline & Con & AA1 & AA2 & $\mathrm{CN} 1$ & & $\begin{array}{c}\text { AA } \\
\text { linear }\end{array}$ & $\begin{array}{c}\text { AA } \\
\text { quadratic }\end{array}$ & $\begin{array}{c}\text { CN1 vs. } \\
\text { AA1 }\end{array}$ \\
\hline \multicolumn{9}{|c|}{ Isotopic enrichment $\left(\mathrm{MPE}^{4}\right)$} \\
\hline Arterial & 3.87 & 3.53 & 3.12 & 3.48 & 0.07 & $<0.01$ & 0.65 & 0.60 \\
\hline Portal & 3.72 & 3.40 & 3.02 & 3.35 & 0.08 & $<0.01$ & 0.76 & 0.68 \\
\hline Hepatic & 3.38 & 3.09 & 2.71 & 3.02 & 0.06 & $<0.01$ & 0.55 & 0.48 \\
\hline Mammary & 3.83 & 3.52 & 3.12 & 3.46 & 0.07 & $<0.01$ & 0.60 & 0.55 \\
\hline \multicolumn{9}{|l|}{ Kinetics (mmol/h) } \\
\hline WB $\mathrm{Ra}^{5}$ & 624 & 700 & 775 & 714 & 17 & $<0.01$ & 0.99 & 0.60 \\
\hline \multicolumn{9}{|l|}{ Glucose utilization $^{6}$} \\
\hline Portal (PDV $\mathrm{PU})$ & 93 & 84 & 67 & 91 & 13 & 0.20 & 0.84 & 0.70 \\
\hline Hepatic $\left(\mathrm{HEP}_{\mathrm{PU}}\right)$ & 22 & 46 & 30 & -24 & 22 & 0.81 & 0.49 & 0.60 \\
\hline Splanchnic $\left(\mathrm{TSP}_{\mathrm{PU}}\right)$ & 112 & 112 & 93 & 79 & 22 & 0.57 & 0.75 & 0.34 \\
\hline Mammary $\left(\mathrm{MG}_{\mathrm{PU}}\right)$ & 471 & 515 & 527 & 547 & 34 & 0.27 & 0.72 & 0.52 \\
\hline \multicolumn{9}{|l|}{ True flux ${ }^{7}$} \\
\hline Portal & 155 & 164 & 135 & 145 & 18 & 0.46 & 0.43 & 0.50 \\
\hline Hepatic & 475 & 554 & 621 & 550 & 31 & 0.01 & 0.90 & 0.94 \\
\hline Splanchnic & 633 & 710 & 757 & 690 & 28 & 0.01 & 0.67 & 0.63 \\
\hline $\mathrm{PDV}_{\mathrm{PU}} / \mathrm{WB} \mathrm{Ra}$ & 0.15 & 0.11 & 0.09 & 0.12 & 0.02 & 0.07 & 0.63 & 0.72 \\
\hline $\mathrm{HEP}_{\mathrm{PU}} / \mathrm{WB} \mathrm{Ra}$ & 0.02 & 0.05 & 0.03 & 0.00 & 0.02 & 0.71 & 0.44 & 0.14 \\
\hline $\mathrm{TSP}_{\mathrm{PU}} / \mathrm{WB} \mathrm{Ra}$ & 0.18 & 0.16 & 0.12 & 0.12 & 0.03 & 0.27 & 0.80 & 0.34 \\
\hline $\mathrm{MG}_{\mathrm{PU}} / \mathrm{WB} \mathrm{Ra}$ & 0.74 & 0.73 & 0.69 & 0.76 & 0.05 & 0.41 & 0.77 & 0.70 \\
\hline Lactose/MG flux & 0.74 & 0.73 & 0.79 & 0.65 & 0.04 & 0.38 & 0.42 & 0.18 \\
\hline Lactose/WB Ra & 0.55 & 0.53 & 0.52 & 0.51 & 0.01 & 0.13 & 0.56 & 0.38 \\
\hline
\end{tabular}

${ }^{1}$ Data are presented as LSM with SEM, given for $\mathrm{n}=5$; 20 observations; determined with a continuous infusion of $\left[6,6{ }^{2} \mathrm{H}_{2}\right]$ glucose.

${ }^{2}$ Abomasal infusion treatments: $\mathrm{Con}=$ water; AA1 = free AA for a total supply at $95 \%$ of MP requirements; AA2 = free AA for a total supply at $120 \%$ of MP requirements; CN1 = sodium caseinate for a total supply at $95 \%$ of MP requirements.

${ }^{3}$ Probability corresponding to the null hypothesis with 3 contrasts: AA linear $=$ contrast Con versus AA2; AA quadratic $=$ contrast Con and $\mathrm{AA} 2$ versus $\mathrm{AA} 1$; and $\mathrm{CN1}$ versus AA1.

${ }^{4} \mathrm{MPE}=$ mole percent excess.

${ }^{5} \mathrm{WB}$ Ra $=$ whole-body rate of appearance.

${ }^{6} \mathrm{PU}=$ utilization from plasma supply.

${ }^{7}$ The true flux is the sum of the net flux plus PU. 


\section{True Contribution of Splanchnic Tissues to WB Ra of Glucose}

The true portal flux of glucose was not affected by infusion of AA, whereas true hepatic and splanchnic fluxes increased $(P=0.01)$ with AA infusion. These parameters did not differ between AA1 and CN1. Overall, the true contributions of portal absorption and liver glucose synthesis, summing the net release plus the utilization from plasma source, averaged 21 and $78 \%$ of WB Ra (Table 7), respectively. The true flux of the splanchnic tissues was not different from WB Ra for any of the treatments.

\section{DISCUSSION}

\section{Increased AA Supply Increased WB Ra of Glucose}

The increment in the WB Ra of glucose in response to increased supply of AA is in agreement with earlier studies conducted in dairy cows (e.g., Clark et al., 1977; König et al., 1984; Putnam et al., 1999; Lemosquet et al., 2009) and in goats (Ranawana and Kellaway, 1977; Lough et al., 1983). In addition, AA supply linearly increased WB Ra with no quadratic effect, whereas König et al. (1984) did not report any difference in WB $\mathrm{Ra}$ in cows receiving 240 or $460 \mathrm{~g}$ of sodium caseinate per day. As mentioned, the increment in WB Ra with AA supply can be related to increased true absorption across the PDV, to the gluconeogenic potential of AA, or both processes. Wolff and Bergman (1972) demonstrated that 5 nonessential AA are predominantly used for glucose synthesis in ruminants, but all AA except leucine and lysine can contribute to gluconeogenesis. Assuming that $100 \%$ of the additional AA supply is absorbed by the mesenteric-drained viscera, removing the AA used to support the extra milk protein secretion, and based on the glucogenic potential of each AA, then conversion of the excess AA to glucose was approximately $100 \%$ of theoretical efficiency, similarly to previous observations ruminants (Lemosquet et al., 2009). Whether this actually occurs or if other changes in glucose metabolism occur requires consideration of tissue metabolism.

\section{Partition of Glucose Utilization}

Glucose utilization by the different tissues should sum to glucose rate of disappearance (Rd) at the WB level, and equals Ra at equilibrium.

$\boldsymbol{P D} \boldsymbol{V}$. The relative contribution of $\mathrm{PDV}_{\mathrm{PU}}$ to WB Rd averaged $12 \%$ of WB $\mathrm{Rd}$ in the current study, within the range reported by Larsen and Kristensen (2009) in dairy cows. In lactating dairy cows, PDV utilization of glucose relative to WB $\mathrm{Rd}$ is smaller than that reported in nonlactating ruminants, owing to the high glucose utilization by the MG. In sheep, the PDV is reported to use between 6 and $44 \%$ of glucose WB Rd (e.g., Bergman et al., 1970; Huntington et al., 1980; Piccioli Cappelli et al., 1997; Majdoub et al., 2003). In steers, Seal and Parker (1996) similarly reported a $\mathrm{PDV}_{\mathrm{PU}}$ of glucose ranging from 11 to $27 \%$ of WB Rd.

Utilization of glucose from the lumen cannot be assessed with the vascular infusion of labeled glucose used in the current study. Utilization by the PDV of glucose from the arterial supply might have been spared as PD$\mathrm{V}_{\mathrm{PU}}$ decreased, but only numerically $(P=0.20)$. This would not have an effect on WB Ra, however, but could spare glucose for peripheral tissue use, including by the MG. El-Kadi et al. (2006) reported that utilization of arterial glucose supply by the PDV was not altered by $\mathrm{CN}$ infusion up to $105 \mathrm{~g} / \mathrm{d}$ in wether sheep.

Liver. The liver uses mainly fatty acids as an energy source, with only limited glucose utilization (Krebs, 1972). Indeed, $\mathrm{HEP}_{\mathrm{PU}}$ was negligible in sheep (Bergman et al., 1970; van der Walt et al., 1983). The results of the present study also show that $\mathrm{HEP}_{\mathrm{PU}}$ in lactating dairy cows was small, only $3 \%$ of WB Rd, in support of the fact that the liver meets its energy requirements from other sources. Such low utilization was not affected by AA supply. Together, the splanchnic tissues used $15 \%$ of WB Rd.

$M G$. By far, the largest user of glucose was the MG, which extracted $73 \%$ of WB Rd, a value comparable to those simulated by the model developed by Hanigan et al. (2001). This ratio is reported to decrease with CN infusion (Lemosquet et al., 2009), but this was not confirmed here. This difference may be due to dietary energy level, which was deficient in the earlier study, but at requirement in the present experiment. As the IE of the artery was almost identical to the IE of the mammary vein, the total utilization was also almost identical to the net flux, which will be discussed below.

Others. Together, the splanchnic tissues and the MG contributed $88 \%$ of WB Rd, with the remainder probably available for muscle and brain utilization. Bergman (1973) indicated that glucose metabolism by the sheep brain is less than $10 \%$ of WB Rd, which would scale to less than $3 \%$ in the dairy cow when the $\mathrm{MG}_{\mathrm{PU}}$ is included. This would leave approximately $10 \%$ of WB Rd, mainly for muscle metabolism. The current cows (average BW of $626 \mathrm{~kg}$ ) are estimated to contain $53.6 \mathrm{~kg}$ of CP (Gibb et al., 1992) and, therefore, muscle utilization of glucose would average $1.2 \mathrm{mmol} / \mathrm{h}$ per $\mathrm{kg}$ of protein, in the low range of values reported in vitro for steer muscle (Rhoades et al., 2007) or slightly lower than values reported for ewes (Ortigues and Durand, 1995). 


\section{True Contribution of Tissues to WB Glucose Ra}

The net flux measurement includes simultaneous release and uptake of glucose by a tissue. Therefore, the true contribution of a tissue to WB Ra is the sum of the net flux plus the utilization of the nutrient by the tissue and will exceed net flux values.

$\boldsymbol{P D V}$. Assuming no change in the amount of glucose disappearing from the small intestine, the net portal appearance of glucose can increase through decreased utilization of glucose from either the arterial or the luminal supply. In the current study, however, the net portal flux of glucose remained unchanged with the treatments, despite the numerical decrease in $\mathrm{PDV}_{\mathrm{PU}}$ observed with the increasing supply of AA. This observation does not support decreased utilization of dietary glucose by the enterocytes through the use of AA as an alternative source of energy. Similarly, El-Kadi et al. (2006) observed, in wether sheep receiving CN infusion into the abomasum, that net portal absorption of glucose was also unaltered. In addition, Doepel et al. (2007) did not find any effect of postruminal glutamine administration on net portal absorption of glucose, again indicating no sparing of glucose across the PDV with the supply of glutamine.

Earlier work reported a null net portal appearance of glucose with hay-based diets (Bergman, 1975), similar to observations made with diets rich in barley, where the starch is rapidly fermented in the rumen, providing only small amounts for digestion in the small intestine (Seal and Parker, 1996). In contrast, diets rich in corn grain provide substantial amounts of starch at the duodenum, with positive net portal absorption of glucose (Huntington et al., 1980). Indeed, a recent metaanalysis reported that net portal appearance of glucose was directly related to the amount of starch digested in the small intestine (Loncke et al., 2009), which itself depends on the dietary starch content, its ruminal degradability and the level of intake (Offner and Sauvant, 2004). The diet in the present study contained 124 and $247 \mathrm{~g}$ of ground corn grain and barley per $\mathrm{kg}$ of DM, respectively, and this probably explains the positive net portal absorption observed $(82 \mathrm{mmol} / \mathrm{h})$. Although the current net portal flux measurements suggest that less than $10 \%$ of the WB glucose $\mathrm{Ra}$ is from dietary origin, in agreement with earlier ruminant studies (Bauman et al., 1971; Otchere et al., 1974), the true contribution of the PDV to WB Ra, including $\mathrm{PDV}_{\mathrm{PU}}$, indicates that the glucose absorbed contributes $21 \%$ of WB Ra.

Liver. Hepatic net release represented $76 \%$ of WB Ra, a proportion unchanged by the treatments. Indeed, most of the incremental WB Ra with increasing AA supply was matched by the extra-hepatic output of glucose. This strongly suggests that the effect on WB
Ra when protein supply is increased originates from liver glucose synthesis. This is achievable based on the known biochemical conversions of AA carbon to glucose, although this would assume a very high efficiency of this process. In contrast, Blouin et al. (2002) reported that increased supply of MP did not affect hepatic glucose release, although increases in milk and lactose production occurred. The true contribution of hepatic metabolism to WB Ra is only slightly higher $(77 \%)$ than the net flux, due to the very small utilization of glucose across the liver.

Others. The total contribution of the splanchnic tissues (PDV plus liver) to WB Ra summed to $99 \%$. This leaves little input for glucose synthesis from other tissues, including mainly the kidneys. In contrast, Kaufman and Bergman $(1971,1974)$ estimated that 8 to $10 \%$ of WB Ra originated from the kidneys in sheep fed hay, and this proportion increased to 15 to $16 \%$ in fasted sheep. All of those studies were conducted with animals fed hay. In heifers, however, Reynolds et al. (1991) observed that the net flux of glucose across the kidneys decreased from 6 to $4 \%$ of the net hepatic release with increasing intake of a $75 \%$ alfalfa diet. Furthermore, on a $75 \%$ concentrate diet, the kidney net flux of glucose was negative. Hence, in lactating dairy cows fed high-concentrate diets, the contribution of kidney glucose synthesis to WB Ra is probably rather limited.

\section{Effect on Glucose Kinetics of AA Supplied in a Free Form or as Protein}

Previous work has suggested that the forms in which AA are supplied, whether as free AA or protein, might induce different responses. In dairy cows, Choung and Chamberlain (1995) reported a greater milk protein yield when the supply $(160 \mathrm{~g} / \mathrm{d})$ was provided as $\mathrm{CN}$ rather than as a mixture of free AA. At a higher level of supply $(320 \mathrm{~g} / \mathrm{d})$, however, both infusions resulted in the same increment in milk and protein yields. This latter finding is supported in the present experiment: neither milk production nor glucose kinetics at the WB, splanchnic, and mammary levels was different between the $\mathrm{CN}(\mathrm{CN} 1)$ and free AA (AA1) treatments at a high supply level of $690 \mathrm{~g} / \mathrm{d}$.

\section{CONCLUSIONS}

Increased supply of AA, either in a free form or as CN, did not affect the true or net fluxes of glucose across the PDV. The treatments did increase hepatic net flux, but liver glucose utilization remained relatively small and unchanged. The augmented glucose synthesis across the liver due to increased AA supply accounted for the 
increase in WB Ra, with conversion efficiency close to theoretical. The form in which AA were supplied, free form or as CN, did not alter glucose response. Further research is needed to continue integrating the interactions between protein and energy metabolism across $\mathrm{PDV}$, liver, and MG in lactating dairy cows.

\section{ACKNOWLEDGMENTS}

The authors express sincere appreciation to R. Martineau [Dairy and Swine Research and Development Centre (DSRDC), Agriculture and Agri-Food Canada, Sherbrooke, QC, Canada] and P. Dubreuil (Faculty of Veterinary Medicine, University of Montreal, St-Hyacinthe, QC, Canada) for their surgical assistance and veterinary care of the animals. The authors gratefully thank F. Dehours, R. Lanctot, D. Thibeault, C. Bolduc, and K. Carter for animal care during the experiment; D. Bournival, M. Léonard, L. Marier, J. Renaud, V. Roy, and P. Warburton for their dedicated technical help, as well as S. Methot for statistical analyses (DSRDC, Agriculture and Agri-Food Canada, Sherbrooke, QC, Canada). The authors also acknowledge the financial support from Dairy Farmers of Canada (Ottawa, ON, Canada), from the Natural Sciences and Engineering Research Council of Canada (Ottawa, ON, Canada), and from Agriculture and Agri-Food Canada (Sherbrooke, QC, Canada). A special thank you is also addressed to Evonik Degussa GmbH (Hanau, Germany) for the supply of free AA.

\section{REFERENCES}

Bauman, D. E., C. L. Davis, and H. F. Bucholtz. 1971. Propionate production in the rumen of cows fed either a control or high-grain, low-fiber diet. J. Dairy Sci. 54:1282-1287.

Bensadoun, A., O. L. Paladines, and J. T. Reid. 1962. Effect of level of intake and physical form of the diet on plasma glucose concentration and volatile fatty acid absorption in ruminants. J. Dairy Sci. $45: 1203-1210$.

Bergman, E. N. 1973. Glucose metabolism in ruminants as related to hypoglycemia and ketosis. Cornell Vet. 63:341-382.

Bergman, E. N. 1975. Production and utilization of metabolites by the alimentary tract as measured in portal and hepatic blood. Pages 192-305 in Proc. 4th Int. Symp. Ruminant Physiol., Armidale, NSW, Australia. I. W. McDonald and A. C. I. Warner, ed. Univ. New England Publishing Unit, Armidale, NSW, Australia.

Bergman, E. N., M. L. Katz, and C. F. Kaufman. 1970. Quantitative aspects of hepatic and portal glucose metabolism and turnover in sheep. Am. J. Physiol. 219:785-793.

Bergman, E. N., C. F. Kaufman, J. E. Wolff, and H. H. Williams. 1974. Renal metabolism of amino-acids and ammonia in fed and fasted pregnant sheep. Am. J. Physiol. 226:833-837.

Bickerstaffe, R., E. F. Annison, and J. L. Linzell. 1974. The metabolism of glucose, acetate, lipids and amino acids in lactating dairy cows. J. Agric. Sci. 82:71-85.

Blouin, J. P., J. F. Bernier, C. K. Reynolds, G. E. Lobley, P. Dubreuil, and H. Lapierre. 2002. Effect of supply of metabolizable protein on splanchnic fluxes of nutrients and hormones in lactating dairy cows. J. Dairy Sci. 85:2618-2630.
Borucki Castro, S. I., H. Lapierre, L. E. Phillip, P. W. Jardon, and R. Berthiaume. 2008. Towards non-invasive methods to determine the effect of treatment of soya-bean meal on lysine availability in dairy cows. Animal 2:224-234.

Brockman, R. P. 1984. Validation of equation for calculation of glucose appearance during nonsteady state in sheep. Can. J. Physiol. Pharmacol. 62:341-344.

Calder, A. G., K. E. Garden, S. E. Anderson, and G. E. Lobley. 1999. Quantitation of blood and plasma amino acids using isotope dilution electron impact gas chromatography/mass spectrometry with $\mathrm{U}_{-}{ }^{13} \mathrm{C}$ amino acids as internal standards. Rapid Commun. Mass Spectrom. 13:2080-2083.

Canadian Council on Animal Care. 1993. Guide to the Care and Use of Experimental Animals. Vol. 1. 2nd ed. E. D. Olfert, B. M. Cross, and A. A. McWilliam, ed. CCAC, Ottawa, ON, Canada.

Choung, J. J., and D. G. Chamberlain. 1995. Effects of abomasal infusion of sodium caseinate, a hydrolysate of casein or a corresponding mixture of free amino acids on milk yield and composition in dairy cows. J. Dairy Res. 62:29-37.

Clark, J. H., H. R. Spires, R. G. Derrig, and M. R. Bennink. 1977. Milk production, nitrogen utilization and glucose synthesis in lactating cows infused postruminally with sodium caseinate and glucose. J. Nutr. 107:631-644.

Doepel, L., M. Lessard, N. Gagnon, G. E. Lobley, J. F. Bernier, P. Dubreuil, and H. Lapierre. 2006. Effect of postruminal glutamine supplementation on immune response and milk production in dairy cows. J. Dairy Sci. 89:3107-3121.

Doepel, L., G. E. Lobley, J. F. Bernier, P. Dubreuil, and H. Lapierre. 2007. Effect of glutamine supplementation on splanchnic metabolism in lactating dairy cows. J. Dairy Sci. 90:4325-4333.

Duffield, T. 1999. A fistful of rumen-A novel approach to rumen fistula surgery. Practice tips. Page 179 in Proc. 32nd Annu. Conf. Am. Assoc. Bovine Pract. Conf., Nashville, TN. Am. Assoc. Bovine Pract., Auburn, AL.

Eisemann, J. H., G. B. Huntington, and C. L. Ferrell. 1987. Blood flow to hindquarters of steers measured by transit time ultrasound and indicator dilution. J. Dairy Sci. 70:1385-1390.

El-Kadi, S. W., R. L. Baldwin VI, N. E. Sunny, S. L. Owens, and B. J. Bequette. 2006. Intestinal protein supply alters amino acid, but not glucose, metabolism by the sheep gastrointestinal tract. J. Nutr. 136:1261-1269.

Gibb, M. J., W. E. Irvings, M. S. Dhanoa, and J. D. Sutton. 1992. Changes in body components of autumn-calving Holstein-Friesian cows over the first 29 weeks of lactation. Anim. Prod. 55:339-360.

Gill, J. L. 1978. Design and Analysis of Experiments in the Animal and Medical Sciences. Vol. 1. Iowa State Univ. Press, Ames.

Gressley, T. F., S. M. Reynal, J. J. Olmos Colmenero, G. A. Broderick, and L. E. Armentano. 2006. Technical note: Development of a tool to insert abomasal infusion lines into dairy cows. J. Dairy Sci. 89:3965-3967.

Hanigan, M. D., L. A. Crompton, J. A. Metcalf, and J. France. 2001. Modelling mammary metabolism in the dairy cow to predict milk constituent yield, with emphasis on amino acid metabolism and milk protein production: Model construction. J. Theor. Biol. 213:223-239.

Huntington, G. B., R. L. Prior, and R. A. Britton. 1980. Glucose and lactate absorption and metabolic interrelationships in lambs switched from low to high concentrate diets. J. Nutr. 110:19041913.

Huntington, G. B., C. K. Reynolds, and B. H. Stroud. 1989. Techniques for measuring blood flow in splanchnic tissues of cattle. J. Dairy Sci. 72:1583-1595.

Katz, M. L., and E. N. Bergman. 1969. A method for simultaneous cannulation of the major splanchnic blood vessels of the sheep. Am. J. Vet. Res. 30:655-661.

Kaufman, C. F., and E. N. Bergman. 1971. Renal glucose, free fatty acid, and ketone body metabolism in unanesthetized sheep. Am. J. Physiol. 221:967-972.

Kaufman, C. F., and E. N. Bergman. 1974. Renal ketone body metabolism and gluconeogenesis in normal and hypoglycemic sheep. Am. J. Physiol. 226:827-832. 
König, B. A., J. D. Oldham, and D. S. Parker. 1984. The effect of abomasal infusion of casein on acetate, palmitate and glucose kinetics in cows during early lactation. Br. J. Nutr. 52:319-328.

Krebs, H. A. 1972. Some aspects of the regulation of fuel supply in omnivorous animals. Adv. Enzyme Regul. 10:397-420.

Larsen, M., and N. B. Kristensen. 2009. Effect of abomasal glucose infusion on splanchnic and whole-body glucose metabolism in periparturient dairy cows. J. Dairy Sci. 92:1071-1083.

Lemosquet, S., G. Raggio, G. E. Lobley, H. Rulquin, J. Guinard-Flament, and H. Lapierre. 2009. Whole-body glucose metabolism and mammary energetic nutrient metabolism in lactating dairy cows receiving digestive infusions of casein and propionic acid. J. Dairy Sci. 92:6068-6082.

Lemosquet, S., J. N. Thibault, A. Thomas, E. Debras, and C. Hurtaud. 2004. Validation of the measurement of glucose appearance rate with $\left[6,6-{ }^{2} \mathrm{H}_{2}\right]$ glucose in lactating dairy cows. Reprod. Nutr. Dev. 44:17-27.

Lindsay, D. B. 1980. Amino acids as energy sources. Proc. Nutr. Soc. 39:53-59.

Loncke, C. I. Ortigues-Marty, J. Vernet, H. Lapierre, D. Sauvant, and P. Nozière. 2009. Empirical prediction of net portal appearance of volatile fatty acids, glucose and their secondary metabolites ( $\beta$-hydroxybutyrate, lactate) from dietary characteristics in ruminants: A meta-analysis approach. J. Anim. Sci. 87:253-268.

Lough, D. S., E. C. Prigge, W. H. Hoover, and G. A. Varga. 1983. Utilization of ruminally infused acetate or propionate and abomasally infused casein by lactating goats. J. Dairy Sci. 66:756-762.

Lozano, O., C. B. Theurer, A. Alio, J. T. Huber, A. Delgado-Elorduy, P. Cuneo, D. DeYoung, M. Sadik, and R. S. Swingle. 2000. Net absorption and hepatic metabolism of glucose, L-lactate, and volatile fatty acids by steers fed diets containing sorghum grain processed as dry-rolled or steam-flaked at different densities. J. Anim. Sci. 78:1364-1371.

Majdoub, L., M. Beylot, M. Vermorel, and I. Ortigues-Marty. 2003. Propionate supplementation did not increase whole body glucose turnover in growing lambs fed rye grass. Reprod. Nutr. Dev. 43:357-370.

Martineau, R., H. Lapierre, D. R. Ouellet, D. Pellerin, and R. Berthiaume. 2007. Effects of the method of conservation of timothy on nitrogen metabolism in lactating dairy cows. J. Dairy Sci. 90:2870-2882.

National Research Council. 2001. Nutrient Requirements of Dairy Cattle. 7th rev. ed. Natl. Acad. Sci., Washington, DC.

Offner, A., and D. Sauvant. 2004. Prediction of in vivo starch digestion in cattle from in situ data. Anim. Feed Sci. Technol. 111:41-56.

Ortigues, I., and D. Durand. 1995. Adaptation of energy metabolism to undernutrition in ewes. Contribution of portal-drained viscera, liver and hindquarters. Br. J. Nutr. 73:209-226.
Otchere, E. O., A. D. McGilliard, and J. W. Young. 1974. Quantitation of $\alpha$-linked glucose polymers passing to the small intestine in cattle. J. Dairy Sci. 57:1189-1195.

Piccioli Cappelli, F., C. J. Seal, and D. S. Parker. 1997. Glucose and $\left[{ }^{13} \mathrm{C}\right]$ leucine metabolism by the portal-drained viscera of sheep fed on dried grass with acute intravenous and intraduodenal infusions of glucose. Br. J. Nutr. 78:931-946.

Putnam, D. E., G. A. Varga, and M. H. Green. 1999. Glucose kinetic responses to protein supplementation and exogenous somatotropin in late gestation dairy cows. J. Dairy Sci. 82:1274-1281.

Raggio, G., D. Pacheco, R. Berthiaume, G. E. Lobley, D. Pellerin, G. Allard, P. Dubreuil, and H. Lapierre. 2004. Effect of level of metabolizable protein on splanchnic flux of amino acids in lactating dairy cows. J. Dairy Sci. 87:3461-3472.

Ranawana, S. S. E., and R. C. Kellaway. 1977. Responses to postruminal infusions of glucose and casein in lactating goats. Br. J. Nutr. 37:395-402.

Reynolds, C. K. 2006. Production and metabolic effects of site of starch digestion in dairy cattle. Anim. Feed Sci. Technol. 130:78-94.

Reynolds, C. K., H. Lapierre, H. F. Tyrrell, T. H. Elsasser, R. C. Staples, P. Gaudreau, and P. Brazeau. 1992. Effects of growth hormone-releasing factor and feed intake on energy metabolism in growing beef steers: Net nutrient metabolism by portal-drained viscera and liver. J. Anim. Sci. 70:752-763.

Reynolds, C. K., H. F. Tyrrell, and P. J. Reynolds. 1991. Effects of diet forage-to-concentrate ratio and intake on energy metabolism in growing beef heifers: Whole body energy and nitrogen balance and visceral heat production. J. Nutr. 121:994-1003.

Rhoades, R. D.. J. E. Sawyer, K. Y. Chung, M. L. Schell, D. K. Lunt, and S. B. Smith. 2007. Effect of dietary energy source on in vitro substrate utilization and insulin sensitivity of muscle and adipose tissues of Angus and Wagyu steers. J. Anim. Sci. 85:1719-1726.

SAS Institute. 2008. SAS/STAT User's Guide. Version 9.2. SAS Institute Inc., Cary, NC.

Seal, C. J., and D. S. Parker. 1996. Effect of intraruminal propionic acid infusion on metabolism of mesenteric- and portal-drained viscera in growing steers fed a forage diet: II. Ammonia, urea, amino acids, and peptides. J. Anim. Sci. 74:245-256.

Swaisgood, H. E. 1995. Protein and amino acid composition of bovine milk. Pages 464-472 in Handbook of Milk Composition. R. G. Jensen, ed. Academic Press, London, UK.

van der Walt, J. G., G. D. Baird, and E. N. Bergman. 1983. Tissue glucose and lactate metabolism and interconversions in pregnant and lactating sheep. Br. J. Nutr. 50:267-280.

Wolff, J. E., and E. N. Bergman. 1972. Gluconeogenesis from plasma amino acids in fed sheep. Am. J. Physiol. 223:455-460.

Young, J. W. 1977. Gluconeogenesis in cattle: Significance and methodology. J. Dairy Sci. 60:1-15. 